\title{
Characterization of stabilized waste: Evaluation of pollution risk
}

\author{
${ }^{1}$ M. Aina, ${ }^{1}$ G. Matejka, ${ }^{2}$ D. Mama, ${ }^{3 *}$ B. Yao, ${ }^{2}$ M. Moudachirou \\ ${ }^{1}$ Laboratoire des Sciences de l'Eau et de l'Environnement de l'Ecole Nationale Supérieure d'Ingénieurs de Limoges; \\ 16 rue Atlantis, Parc Ester Technopole 87068 Limoges, France \\ ${ }^{2}$ Laboratoire d'expertise et de Recherche en Chimie de l'Eau et de l'Environnement de l'Université d'Abomey Calavi, \\ 01 BP 526 Cotonou, Benin \\ ${ }^{3}$ Laboratoire des Procédés Industriels de Synthèse et de l'Environnement de l'Institut National Polytechnique \\ Houphouët-Boigny, BP, 1093 Yamoussoukro, Côte d'Ivoire
}

Received 5 August 2008; $\quad$ revised 25 October 2008; accepted 12 November 2008; $\quad$ available online 10 December 2008

\begin{abstract}
This study relates to the characterization of stabilized waste. Various parameters such as granulometric distribution, percentage of mineral and organic matter were estimated to appreciate environmental hazard potential and possibility of metal leaching of the samples of waste from Grange site in France. From the results, it was shown that the granulometric distribution was variable. Therefore, a strong proportion of fines (44.6 \%) and medium (45.9 \%) was observed due to the age of waste that supports the degradation of a great quantity of organic matter. That was confirmed by the strong mineral matter rate (63.8 \%) obtained to determine the organic percentage of matter (36.2 \%). The amount of heavy metals such as iron, nickel, copper, zinc, cadmium and lead was also studied. The results obtained were in a good agreement with the ones of the literature. Indeed, it appeared that iron, lead, copper, nickel and zinc are in relative strong proportion while cadmium was not very present. Iron represents $78 \%$ of the metals. From the leaching tests, it was shown that the heavy metals concentration were very weak. Moreover, the deposit of studied waste could be a potential source of organic pollution (COD $=150 \mathrm{Mg}$ C/L on average) in the case of precipitation and flood.
\end{abstract}

Key words: Ageing landfill material, organic matter, heavy metals, soil contamination, leaching test

\section{INTRODUCTION}

Waste management constitutes one of the major problems for urban cities. Their production is important and in constant increasing because of the demographic explosion and the development of commercial and industrial activities. The setting in discharge of municipal solid waste represented for a long time the common way of elimination because of its low cost. However, this waste contains innumerable species that evolve progressively according complexes chemical and biological mechanisms toward stabilized waste (in last phase of degradation or not being able more to undergo degradation) (Rich et al., 2007). Indeed, it is important to note that while ageing, a landfill undergoes biologically, chemically, geologically and hydrologically mediated changes resulting in a weathering process (Bookter et al., 1982; Mata-Alvarez, 2003; Gachet, 2005; Sponza and Agdad, 2005). This low process can be divided into anaerobic and aerobic 凶* *orresponding Author Email: beyao@yahoo.fr Tel.: +225 0780 0519; Fax: +225 30640406 phase (Östman et al., 2006). In the literature, it was shown that stabilized waste contained an important quantity of heavy metals which were found only in very small proportion in the leachate (Christensen et al., 1996; Azita and Catherine, 2008; Ogundiran and Afolabi, 2008; Östman et al., 2008). This fact supposes that these metals either are complexed by the organic matter or trapped in the form of sulphides (Reuter and Perdue, 1977; Bruemmer et al., 1986; Ciavatta et al., 1993). This study relates to the characterization of the stabilized waste taken in a center of storage of urban and old waste from 18 to $20 \mathrm{y}$. The evolution of stabilized waste, according to the conditions of acidification, oxidation and complexation was considered in order to apprehend the future of heavy metals trapped in this waste evaluating their mobility. Indeed, it is very important to evaluate the risk for these metals to be release in water resources (Baumann et al., 2006) and grounds via an acidification and/or oxygenation of the 
tock in hidden waste (Matejka et al., 1999). The burying of the household refuse in the natural environment, apart from our spaces of life, is the oldest, less expensive and common way of the waste disposal. The increase in the production of waste, in particular within the urban community will make necessary the control of this deposit. The structures of deposit evolved in order to limit the environmental impacts. The improvement of the techniques makes it possible today to foresee new types of storage which before being dies of elimination, will be dies of valorization. Therefore, the harmful effects produced by old deposit such as olfactory effects, air pollution, soils contaminations and pollution of grounds waters remain important (Sloczynska and Slomczynski, 2004; Mwiganga and Kansiime, 2005; Shouliang et al., 2008). Few thorough analytical works on rough or pretreated waste were mentioned because of the difficulty to apply the experimental protocols and methods due to the heterogeneity of the substrate. It should be noted that in such system only the fermentable matter and paper in a lesser extend undergo the effect of degradation. Metals can evolve, but do not disappear. Great quantities of metals were thus hidden during the storage of urban and industrial waste. Table 1 indicates the concentrations of metals in waste. These contents of heavy metals were estimated according to several ways, but whatever the methods used, the results are often variable and with important uncertainties. Rouyer (1990) indicates that, whatever precautions taken during the development, the execution, the analysis of the sample and the variation coefficients of measurements are generally higher than 100 due to the heterogeneity of the composition of the household refuse. The presented data related to only household refuse (or urban waste) and it should be noted that the industrial waste contains higher heavy metal concentrations (Rinke, 1999). In the sediment polluted by industrial waste, the lead $(\mathrm{Pb})$ amounts vary from 1.3 to $757.8 \mathrm{mg} / \mathrm{kg}$. Aulin and Neretninieks (1995) estimated that concentrations of $\mathrm{Cu}, \mathrm{Cd}, \mathrm{Zn}, \mathrm{Hg}$ and $\mathrm{Pb}$ were 5 to 127 times higher in the discharges than in the original grounds. It is showed that the release of metal occurred according to two mechanisms: The saturation of the capacity plug, the changes of chemical nature which decreased the adsorption or the capacities of adsorption of toxic metals. The authors concluded that a discharge in which oxidation or oxidation-acidification occurred, the second mechanism was preponderant (Lagier, 2000; Lagier et al., 2001).

\section{MATERIALS AND METHODS}

Samples were provided from an 18 to 20 y old technical hiding and were collected at two points (2 and $3 \mathrm{~m}$ depth). Lixiviates came from the discharge of household refuse opened in 1974. This area, subjected to oceanic climate, is characterized by mean pluviometry (approximately $860 \mathrm{~mm} / \mathrm{y}$ ) and a potential evaporation of $680 \mathrm{~mm} / \mathrm{y}$. For the elution test (Wagner and Vasel, 1998) a mass of waste, crushed, dried and filtered was mixed with a defined mass of water. The ratio of both is called L/S (liquid/solid). The traditional tests of elution were carried out during $24 \mathrm{~h}$ with a mass of waste not exceeding $100 \mathrm{~g}$ of dry matter under controlled agitation. From these tests, the water soluble quantities of elements were easily estimated. Several extractions with a weak ratio $\mathrm{L} / \mathrm{S}$ (for example $\mathrm{L} / \mathrm{S}=1$ ) using the same elution solution provided a maximum concentration. On the other hand, a succession of elution with high ratios L/S (about 10) with solutions renewed each time gave results on the maximum extractable quantities. In the presented case, $100 \mathrm{~g}$ of dried, crushed and filtered waste was used. The tests were carried out with hermetic plastic bottles with a ratio of L/S $=8$ under agitation during 3 to 4 days. Samples were taken at 6, 24, 48, 72, $96 \mathrm{~h}$. The $\mathrm{pH}$ of the solutions was performed using a $\mathrm{pH}$ meter (TACUSSEL) and the calibration of the apparatus is carried out using 2 buffer solutions of $\mathrm{pH} 7$ and 4 while the conductivity was carried out using a conduct meter (LF 538 WTW). The analyses of COD was carried out according to AFNOR standards (NFT 90-101).

Table 1: Contents of heavy metals in the household refuse

\begin{tabular}{|c|c|c|c|c|c|c|c|c|}
\hline \multirow[t]{2}{*}{ Authors } & \multirow[t]{2}{*}{ Types of waste } & \multicolumn{7}{|c|}{ Contents of mg/kg (SM) } \\
\hline & & $\mathrm{Hg}$ & $\mathrm{Cd}$ & $\mathrm{Pb}$ & $\mathrm{Zn}$ & $\mathrm{Cu}$ & $\mathrm{Ni}$ & $\mathrm{Cr}$ \\
\hline Rousseau et al.,1990 & Domestic refuse & 3.4 & 5.3 & $268-320$ & 634 & 49 & 16 & $50-70$ \\
\hline Rousseau et al.,1990 & Domestic refuse & 4.8 & 44 & 556 & 1085 & 240 & 50 & $70-93$ \\
\hline Rouyer, 1990 & Urban waste & $<1$ & 10.5 & 387 & 2259 & 865 & 200.3 & 426 \\
\hline Rinke, 1999 & Urban waste & - & 14.7 & 745 & 1072 & 235 & - & - \\
\hline Ranges of values & & $0.1-5$ & $1.5-44$ & & $400-2300$ & $100-900$ & $15-200$ & $50-100$ \\
\hline
\end{tabular}


The organic matter content is defined by the method of the weight loss (Moreno et al., 2001). Measurements of dissolved organic carbon were performed by a carbon analyzer (O. I. Analytical model 1010). After acidification of the sample by phosphoric acid, mineral carbon $\left(\mathrm{CO}_{2}\right)$ was eliminated by bubbling of nitrogen. The sodium persulphate was then introduced into the sample. This oxidant reacted with the organic carbon of the sample at $100{ }^{\circ} \mathrm{C}$ to give $\mathrm{CO}_{2}$. This last was purged again and was detected by infra-red. From the $\mathrm{CO}_{2}$ quantity, the carbon mass of the sample was estimated. The threshold of detection is estimated at $0.2 \mathrm{mg} \mathrm{C/L}$. The cations and anions were performed by ionic chromatography on a Dionex apparatus DX 100. Measurements of absorbance UV were carried out using a spectrophotometer UV visible MC2 Safas with double beam of bandwidth $1 \mathrm{~nm}$. The precision of unit wavelength is 0.005 between 220 and $700 \mathrm{~nm}$. The sequential extraction of metals from the matrix is carried out and different fractions were obtained according to the method of Tessier et al., (1979). The concentrations in metal ions such as $\mathrm{Fe}, \mathrm{Ni}, \mathrm{Cu}, \mathrm{Zn}, \mathrm{Cd}$ and $\mathrm{Pb}$ were determined by atomic absorption on a Varian Spectra AA 800 equipped with a system of Zeeman correction of non atomic absorption due to the residual matrix. The limit of detection was about $0.1 \mu \mathrm{g} / \mathrm{L}$ and was variable according to the element proportioned. Two spectrophotometers atomic absorption flame (SAFAS) AA 181 and VARIAN AA 180 of variable limit of detection according to elements were also used. The samples were preliminary mineralized with a boiling mixture of $\mathrm{HCl}$ and $\mathrm{HNO}_{3}(75 \% \mathrm{v} / \mathrm{v}$ of $\mathrm{HCl})$ either in a Pyrex Matras or in a system of furnace microwaves according to the program of temperature XP 15000 GROUND MEL.Taking into account the interferences observed during proportioning, the analyses were carried out on masses of $0.1 \mathrm{~g}$ waste.

\section{RESULTS AND DISCUSSION}

The granulometric distribution for the two samples is variable as shown in Table 2. Nevertheless, a high proportion of fines and means is observed due to degradation of the organic part of the waste. Table 3 illustrates chemical composition of the studied wastes. No significant difference is observed between the two samples in spite of their granulometric difference. One could expect an organic matter rate higher in the sample 2 which presents a high proportion of fines. A high quantity of iron (about $35 \%$ ) is observed. This value must be considered with carefulness because of the probable interferences (sulphates for example) during the use of absorption spectrophotometer. The evolution of the oxydable matters release as a function of the time for sample 1 is depicted by Fig. 1 . It can be noted that whatever the used elution solution a stage is reached at $48 \mathrm{~h}$. This stage is indication of an equilibrium state of the release potential of the waste and shows that in spite of heterogeneity in phase of waste stabilization, there is a residual release of pollution. Consequently, the deposits of waste represent potential sources of organic pollution. The follow up of dissolved organic carbon allows the estimation of the release capacity of the carbon organic matter. Fig. 2 shows the evolution of dissolved organic carbon and pH. From Figs. 2 a and c, it can be noted that the COD reaches an equilibrium states at $24 \mathrm{~h}$. These states depend on the elution solution nature and translate a state of balance of the system. The stable observed value of COD seems to traduce a maximum release in the case of stabilised waste. Moreover, from Fig. 2b, an increasing evolution of the COD and $\mathrm{pH}$ for the bicarbonate solution is observed. The COD is the greatest part of the contaminants of subsoil waters and can influence the becoming of the other contaminants because of its implication in the complex processes such as reduction, precipitation and/or complexation. It is known not only to play a role in the transfer of heavy metals, but also to interact with the organic micro pollutants (pesticides, etc). These strong concentrations of the COD obtained by release in demineralised water and bicarbonated water would be related to the presence of strong molecular weight compounds resulting from the polymerization molecules during the process of biological degradation and even from vegetation and animal wastes oxidation (Thurman, 1985). This can support the processes of

Table 2: Granulometric distribution of waste

\begin{tabular}{lccr}
\hline Granulometry & Sample 1 & Sample 2 & \multicolumn{1}{c}{ Average } \\
\hline \% large $(>10 \mathrm{~cm})$ & 7.40 & 11.6 & $9.40 \pm 2.96$ \\
\% average $(2 \mathrm{~cm}<\Phi<10 \mathrm{~cm})$ & 52.3 & 39.5 & $45.90 \pm 9,05$ \\
$\%$ fines $(<2 \mathrm{~cm})$ & 40.3 & 48.8 & $44.60 \pm 6.01$ \\
\hline
\end{tabular}

Table 3: Chemical composition of waste

\begin{tabular}{|c|c|c|c|c|c|}
\hline \multirow{2}{*}{ Sample } & \multirow{2}{*}{$\begin{array}{c}\text { Organic } \\
\text { matter (\%) }\end{array}$} & \multicolumn{2}{|c|}{ Mineral matter (\%) } & \multirow{2}{*}{$\begin{array}{c}\text { Organic } \\
\text { C (\%) }\end{array}$} & \multirow{2}{*}{ NTK (\%) } \\
\hline & & Other (\%) & Iron (\%) & & \\
\hline & 36.4 & 33 & 30. & 21.5 & \\
\hline 102 & 36.0 & 30 & 34 & 17.0 & 0.84 \\
\hline Average & $36.2 \pm 0.3$ & $31.5 \pm 2.1$ & $32.3 \pm 2.4$ & $19.3 \pm 2.8$ & $2.34 \pm 0.46$ \\
\hline
\end{tabular}




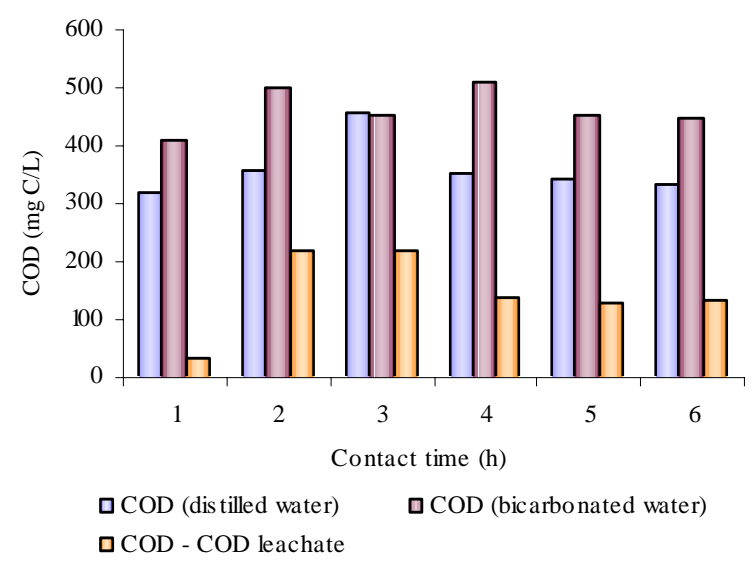

Fig. 1: Sample $1 \mathrm{COD}$ as a function of the contact time

complexation in hidden waste and thus influence the remobilisation of metals knowing that this organic matter can, at the same time, immobilize metals or increase their mobility (complexation by the humic substances in particular acids fulvic). However, the low values of the absorbance in the leachate shows that the organic carbon do not depend necessarily on humic substances. Consequently, the deposit of studied waste can be a potential source of organic pollution (COD $=150 \mathrm{Mg} \mathrm{C} / \mathrm{L}$ on average) in the case of precipitation and flood. Finally, the leachate can be considered as a stabilized one. In accordance with the bibliography, the heavy metal concentrations of the leachate of Crézin are very weak as shown by Tables 4 and 5. However, a possible interference of other mineral matters is probable during the proportioning. However, this has not been studied here. The results represent average values obtained from several tests and are in the range of value of the bibliography. $\mathrm{Pb}, \mathrm{Cu}, \mathrm{Ni}$ and $\mathrm{Zn}$ are in strong proportion and cadmium is not present in large amount. The two analyzed samples present almost the same metals contents. The weak observed difference is due to the strong proportion of fines in the sample 2 which would result either from degradation or crushing. In this case, they would be crushed with important quantities of metals and can explain the slightly higher contents in sample 2 compared to the sample 1 . These results compared with those generally obtained in old leachates come to confirm the assumption according to which an important quantity of metals remains buried in the discharges of household refuse. The sequential extraction of metals from the matrix, carried out according to the method of Tessier et al., (1979), gave
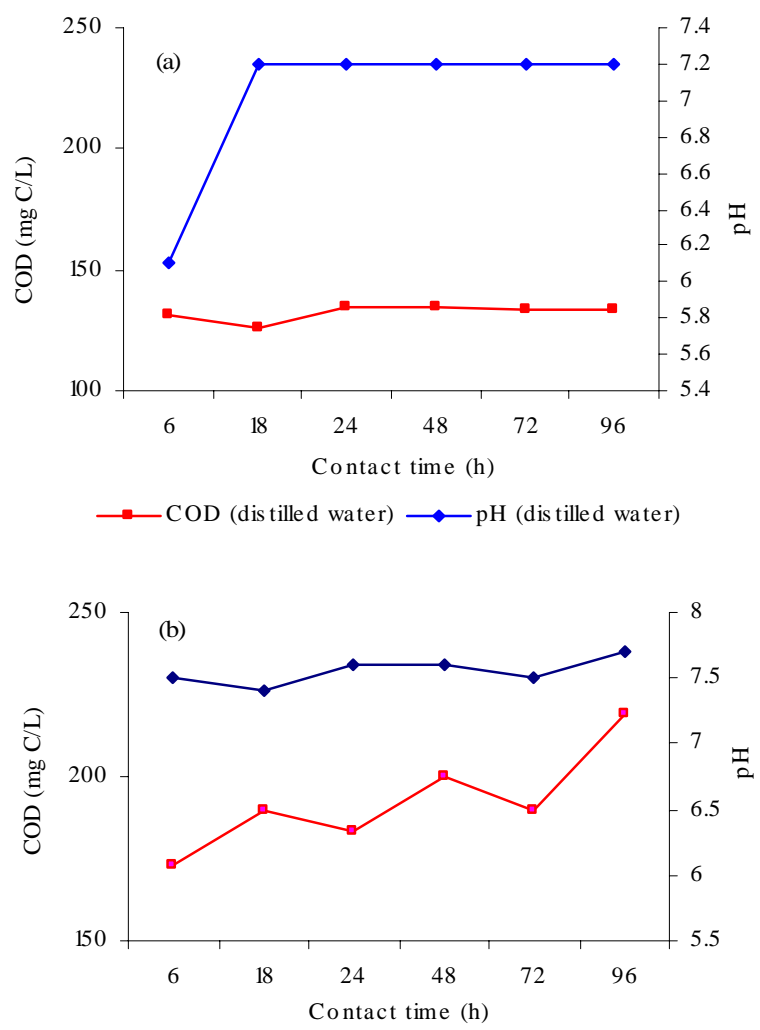

$\longrightarrow$ COD bicarbonated water) $\longrightarrow$ pH (bicarbonated water)

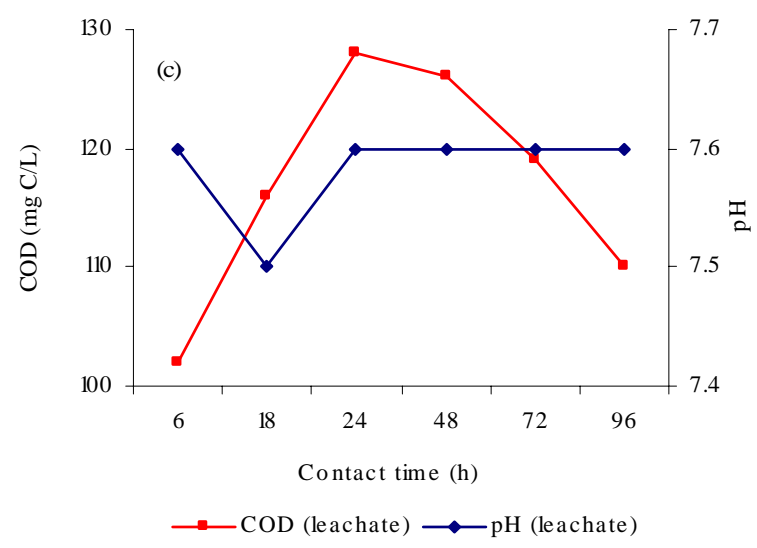

Fig. 2: $\mathrm{COD}$ and $\mathrm{pH}$ as a function of the time

five fractions. The results are depicted in Fig. 3. Copper, nickel and to a lesser extent zinc and cadmium are strongly complexed with the organic matter and sulphides. Lead is practically not complexed with the organic matter. Moreover, copper is mainly in the form of sulphide and organic complex (fraction 4). It is also found in the fraction 5 , but practically non existent in exchangeable form. The affinity of copper for the 
Int. J. Environ. Sci. Tech., 6 (1), 159-165, Winter 2009

Table 4: Contents of metals in the lixiviate of Crézin

\begin{tabular}{lrrrrrr}
\hline Metals & \multicolumn{1}{c}{$\mathrm{Fe}$} & $\mathrm{Ni}$ & $\mathrm{Cu}$ & $\mathrm{Zn}$ & $\mathrm{Cd}$ & $\mathrm{Pb}$ \\
\hline Content $(\mu \mathrm{g} / \mathrm{L})$ & 1165 & 200 & 74 & 42 & 5 & 4 \\
Precision $(\mu \mathrm{g} / \mathrm{L})$ & \pm 6 & \pm 6 & \pm 5 & \pm 2 & \pm 2 & \pm 4 \\
Content $(\mu \mathrm{mol} / \mathrm{L})$ & 21 & 3.4 & 1 & 0.6 & - & - \\
\hline
\end{tabular}

Table 5: Contents of heavy metals in stabilized waste

\begin{tabular}{lccc}
\hline Metal & $\begin{array}{c}\text { Precision } \\
(\mathrm{mg} / \mathrm{kg})\end{array}$ & $\begin{array}{c}\text { Sample 1 } \\
(\mathrm{mg} / \mathrm{kg})\end{array}$ & $\begin{array}{c}\text { Sample 2 } \\
(\mathrm{mg} / \mathrm{kg})\end{array}$ \\
\hline $\mathrm{Cd}$ & \pm 2 & 15.6 & 16.6 \\
$\mathrm{Cu}$ & \pm 3 & 225.8 & 362 \\
$\mathrm{Ni}$ & \pm 3 & 131.7 & 144.8 \\
$\mathrm{~Pb}$ & \pm 5 & 339.4 & 374.7 \\
$\mathrm{Zn}$ & \pm 2.5 & 198.9 & 219.6 \\
\hline
\end{tabular}

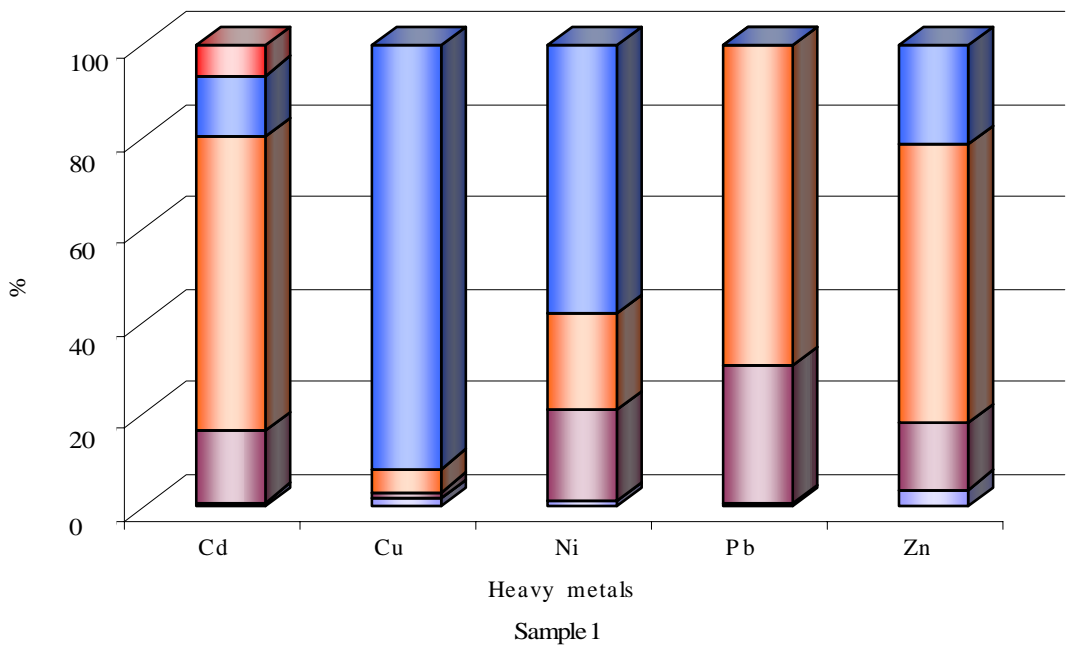

$\square$ fraction $1 \square$ fraction $2 \square$ fraction $3 \square$ fraction $4 \square$ fraction 5

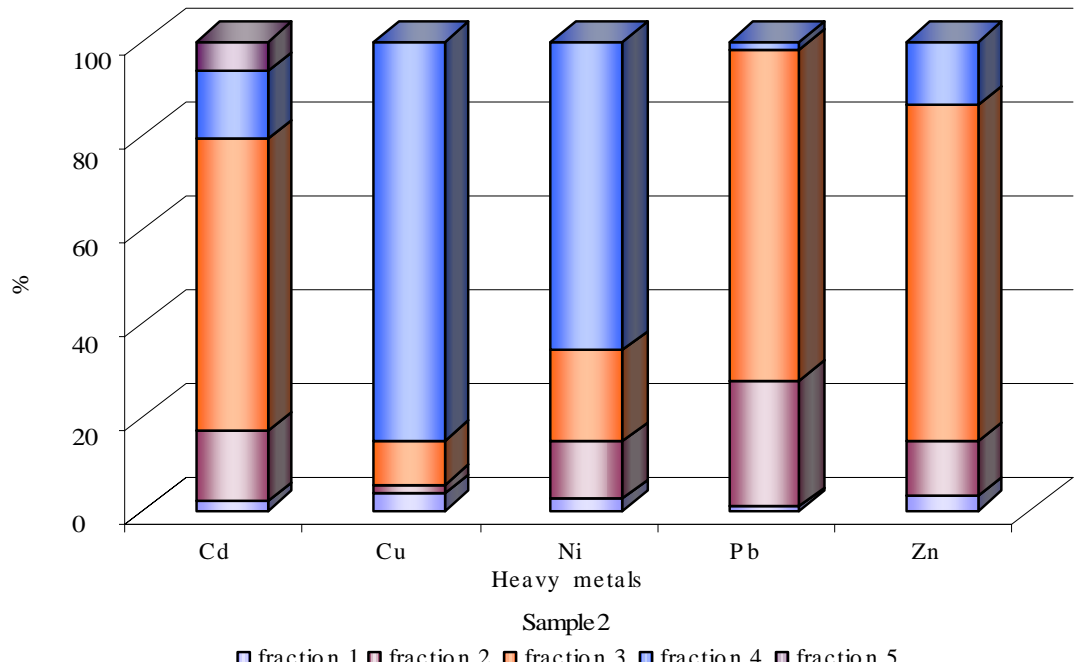

Fig. 3: Percentage of heavy metals for each fraction organic matter is often evoked in the literature (Mårtensson et al., 1999; Rinke, 1999; Lagier, 2000; Berthe, 2006). Copper appears the weak and strong organic complexes molar mass which can be formed in the phase of acidogenesis and methanogenesis. The strong proportion of copper in fraction 4 is explained by its fast adsorption on the surface sites compared to other metals. Moreover, nickel is distributed uniformly 
in fractions 2 and 3. Lead presence in fraction 3 and 4 accounts for approximately $98 \%$ of the total content while in the residual and organic fraction it is in very small proportion. Cadmium and zinc present intermediate speciation with prevalence for fraction 3. These connections with oxyhydroxides of iron and manganese are well known in the literature (Rinke, 1999). All studied metals (Cd, Cu, Ni, Pb and $\mathrm{Zn}$ ) are in small proportion in fraction 1 . However, some of them such as $\mathrm{Cd}$ and $\mathrm{Zn}$ are found in strong proportion in fraction 3. This fact can be explained by the increasing of the $\mathrm{pH}$ and redox potential $\mathrm{E}_{\mathrm{H}}$ during the stabilization phase of waste. Another explanation related to the operating conditions of the sequential extraction can be considered. Indeed, it is possible that during the extraction, part of exchangeable metals could be adsorbed on the oxide-hydroxide ferric phase formed under aerobic conditions. The results obtained with sample 2 confirm the distribution observed with sample 1. However, the proportions observed for the refractory fraction are weak compared to those of sample 1 except for the copper which presents the same contents in fractions 4 and 5 .

\section{REFERENCES}

AFNOR, (1986). Détermination de la demande chimique en oxygène (DCO): NF T 90-101, ISO International Norm, ISO 6060, Recueil de Normes Françaises.

Aulin, C.; Neretnieks, I., (1995). A material balance for an industrial landfill. In proceeding Sardinia 95, $5^{\text {th }}$ International waste management and landfill symposium, Christensen $\mathrm{T}$. H., Cossu, R.; Stegmann, R. (Eds.), CISA. Cagliari., Italy, 3, 173-180.

Azita, H. M.; Catherine, N. M., (2008). Leaching of heavy metals from chromated copper arsenate (CCA) treated wood after disposal., Waste Manage., 28 (3), 628-637.

Baumann, T.; Fruhstorfer, P.; Klein, T.; Niessner, R., (2006). Colloid and heavy metal transport at landfill sites in direct contact with ground water., Water Res., 40 (14), 2776-2786.

Berthe, C., (2006). Etude de la matière organique contenue dans des lixiviats issus de différentes filières de traitement des déchets ménagers et assimilés. Ph.D Thesis., 196.

Bookter, T. J.; Ham, R. K., (1982). Stabilization of solid waste in landfills., J. Environ. Eng., 108 (6), 1089-1100.

Bruemmer, G. W.; Gerth, J.; Herms, U., (1986). Heavy metal species, mobility and availability in soils., J. Plant Nutr. Soil Sc., 149, (4), 382-398

Christensen, J. B.; Jensen, D. L.; Christensen, T. H., (1996). Effect of dissolved organic carbon on the mobility of cadmium, nickel and zinc in leachate polluted groundwater., Water. Res., 30 (12), 3037-3049.

Ciavatta, C., Govi, M., Simoni, A.; Sequi, P., (1993). Evaluation of heavy metals during stabilization of organic matter in compost producted with municipal solid wastes., Bioresource Tech., 43 (2), 147-153
Feuillade, G.; Lagier, T.; Matejka, G., (2001). Les métaux lourds dans les décharges d’ordures ménagères: Synthèse des connaissances. Partie II: synthèse des connaissances., La Tribune de l'eau, 54 (611), 25-36.

Gachet, C., (2005). Evolution bio-physico-chimique des déchets enfouis au Centre de Stockage de Déchets Ultimes du SYDOM du Jura sous l'effet de la recirculation des lixiviats. Thèse de doctorat, INSA Lyon.

Lagier, T., (2000). Etude des macromolécules de lixiviat: caractérisation et comportement vis à vis des métaux, thèse de doctorat, Université de Poitiers, Poitiers, France.

Mata Alvarez, J., (2002). Biomethanization of the organic fraction of municipal solid wastes. 323, IWA publishing, London, UK.

Matejka, G.; Rinke, M.; Lagier, T., (1999). Ground contamination of four municipal landfills: Characterization and evolution of metallic, $7^{\text {th. }}$ International waste management and landfills symposium, Cagliari, Italy.

Mårtensson, A. M.; Aulin, C.; Wahlberg, O.; Ågren, S., (1999). Effect of humic substances on the mobility of toxic metals in a mature landfill., Waste Manage. Res., 17 (4), 296-304.

Moreno, M. T.; Audesse, P.; Giroux, M.; Frenette et, N.; Cescas, M., (2001). Comparaison entre la détermination de la matière organique des sols par la méthode de Walkley-Black et la méthode de perte au feu., Agrosol, 12 (1), 49-58.

Mwiganga, M.; Kansiime, F., (2005). The impact of Mpererwe landfill in Kampala-Uganda, on the surrounding environment., J. Phys. Chem. Earth, Parts A/B/C, 30 (1116), 744-750.

Ogundiran, O. O.; Afolabi, T. A., (2008). Assessment of the physicochemical parameters and heavy metals toxicity of leachates from municipal solid waste open dumpsite., Int. J. Environ. Sci. Tech., 5 (2), 243-250.

Östman, M.; Wahlberg, O.; Agren S.; Martensson, A., (2006). Metal and organic matter contents in a combined household and industrial landfill., Waste Manage., 26 (1), 29-40.

Östman, M.; Wahlberg, O.; Mårtensson, A., (2008). Leachability and metal-binding capacity in ageing landfill material., Waste Manage., 28, (1), 142-150.

Rich, C.; Gronow, J.; Voulvoulis, N., (2007). The potential for aeration of MSW landfills to accelerate completion., Waste Management, 26, (6), 1039-1048.

Rinke, M., (1999). Migration de la pollution minérale dans les sols sous les décharges d'ordures ménagères: étude de cas. Thèse de doctorat, Université de Limoges.

Rousseau, P.; Navarro, A.; Vermande, P., (1990). Distribution des 7 principaux métaux lourds dans les constituants des ordures ménagères. Tribune de l'eau, 42 (5), 17-25.

Reuter, J. H.; Perdue, E. M., (1977). Importance of heavy metal- organic matter interactions in natural waters., Geochim. Cosmochim. Ac., 41, (2), 325-334

Rouyer, P., (1990). Spéciation et élimination des métaux lourds dans les résidus de digestion anaérobie des déchets urbains. Thèse de doctorat, Université de Montpellier II.

Shouliang, H.; Beidou, X.; Haichan, Y.; Liansheng, H.; Shilei, F.; Hongliang, L., (2008). Characteristics of dissolved organic matter (DOM) in leachate with different landfill ages., J. Environ. Sci., 20 (4), 492-498.

Sloczynska, B.; Slomczynski, T., (2004). Physico-chemical and toxicological characteristics of leachates from MSW landfills., Pol. J. Environ. Stud., 13 (6), 627-637 
Sponza, D. T.; Agdad, O. N., (2005). Effect of shredding of wastes on the treatment of municipal solid wastes (MSWs) in simulated anaerobic recycled reactors., Enzyme Microb. Tech., 36 (1), 25-33.

Tessier, A.; Campbell P. G. C.; Bison, M., (1979). Sequential extraction procedure for the speciation of particulate trace metals., Anal. Chem., 51 (7), 844-851.
Thurman, E. M., (1985). Developments in biochemistry : organic geochemistry of natural waters, in: Nijhoff M., Junk, W., (Eds.), Publishers, Dordrecht, Netherlands.

Wagner, G.; Vasel, J. L., (1998). Tests de lixiviation/percolation en colonnes sur ordures ménagères, en vue de la caractérisation des lixiviats d'un centre d'enfouissement technique. Tribune de l’Eau, 590/591, 35-48.

\section{AUTHOR (S) BIOSKETCHES}

Aina, M., M.Sc., Ph.D. in chemistry and microbiology of the water, Researcher in University of Limoges, France. Email: marnickson@yahoo.fr

Matejka, G., M.Sc., Ph.D. in chemistry, professor in University of Limoges, GRESE, ENSIL, France.

Email: matejka@ensil.unilim.fr

Mama, D., M.Sc., Ph.D. in chemistry and environmental engineering, Assistant professor in Faculty of Science and Technology - University of Abomey - Calavi, Benin. Email: mkdaouda@yahoo.fr

Yao, B., M.Sc., Ph.D. in industrial science, professor in the Polytechnic National Institute Houphouët-Boigny of Yamoussoukro, Ivory Coast. Chief of the Industrial Process, Synthesis and Environmental Laboratory. Email:beyao@yahoo.fr

Moudachirou, M., M.Sc., Ph.D. in organic chemistry, professor in Faculty of Science and Technology University of Abomey - Calavi, Benin. Email: moudmans@yahoo.fr

\section{This article should be referenced as follows:}

Aina, M.; Matejka, G.; Mama, D.; Yao, B.; Moudachirou, M., (2008). Characterization of stabilized waste: Evaluation of pollution risk. Int. J. Environ. Sci. Tech., 6 (1), 159-165. 